\title{
Pengembangan Buku Kerja Pengantar Dasar Matematika Berbasis Konstruktivisme
}

\author{
Zulfitri Aima ${ }^{1 *}$, Rahima ${ }^{2}$ \\ ${ }^{1,2}$ STKIP PGRI Sumatera Barat \\ *zulfitri_aima@yahoo.co.id
}

Diterima: Oktober 2019. Disetujui: Desember 2019. Dipublikasikan: Januari 2020

\begin{abstract}
ABSTRAK
Penelitian ini bertujuan untuk mengembangkan buku kerja berbasis konstruktivisme yang valid untuk materi himpunan di STKIP PGRI Sumatera Barat. Materi himpunan diajarkan pada mata kuliah Pengantar Dasar Matematika pada mahasiswa semester 2. Penelitian ini menggunakan rancangan penelitian model Plomp yang terdiri dari 3 fase yaitu: (i) preliminary research, (ii) prototyping phase, dan (iii) assessment phase. Untuk penelitian ini hanya sampai tahap prototyping phase. Hasil angket dan pedoman wawancara menyatakan bahwa buku kerja praktis digunakan. Hasil penelitian ini menunjukkan bahwa buku kerja berbasis konstruktivisme Pengantar Dasar Matematika valid dari segi kelayakan isi, penyajian, kebahasaan, dan kegrafikaan, serta praktis digunakan berdasarkan waktu, penggunaan, dan manfaat.

Kata kunci:. validitas, buku kerja, konstruktivisme, himpunan.
\end{abstract}

\section{ABSTRACT}

The objective of this study is to develop a valid workbook based of constructivism for the material set at STKIP PGRI West Sumatra. The material of the set is taught in the Basic Mathematics Introduction course in the 2nd grade students. This study uses a Plomp model research design consisting of 3 phases: (i) preliminary research, (ii) prototyping phase, and (iii) assessment phase. For this study only to the Prototyping phase. The results show that constructivism-based workbooks for the set matter are valid in terms of content feasibility, presentation, language, and chart.

Keywords: validity, workbook, constructivism, set.

How to Cite: Zulfitri, A. \& Rahima. (2020). Pengembangan Buku Kerja Pengantar Dasar Matematika Berbasis Konstruktivisme. Journal of Medives: Journal of Mathematics Education IKIP Veteran Semarang, 4(1), 161-171. 


\section{PENDAHULUAN}

Mempelajari matematika dapat melatih cara berpikir dan menarik kesimpulan, serta dapat mengembangkan kemampuan pemecahan masalah. Jika dikaitkan dengan perkuliahan matematika pada Perguruan Tinggi, matematika diharapkan dapat menjadikan mahasiswa aktif berpikir sehingga dapat menarik suatu kesimpulan dan dapat memecahkan masalah. Salah satu cabang ilmu yang dipelajari dalam matematika pada perguruan tinggi adalah Pengantar Dasar Matematika. Cabang ilmu ini mempelajari himpunan dan logika.

Materi himpunan dipelajari pada perkuliahan Pengantar Dasar Matematika oleh mahasiswa semester 2 Program Studi Pendidikan Matematika. Nugraha \& Dwiyana (2014: 1.1) mengatakan penguasaan konsep dan ruang lingkup materi himpunan sangat penting karena semua cabang matematika bertumpu pada konsep dasar dan teori himpunan. Dengan dipelajari materi ini, diharapkan mahasiswa mampu menjelaskan definisi himpunan, menyelesaikan operasi pada himpunan, menjelaskan definisi produk kartesius, menjelaskan definisi relasi dan mampu membedakan jenis-jenis relasi, menjelaskan definisi fungsi, membedakan jenis-jenis fungsi, menjelaskan hukum-hukum aljabar himpunan, menjelaskan kardinalitas, dan menjelaskan argumen beserta pembuktiannya.

Proses perkuliahan Pengantar Dasar Matematika di STKIP PGRI Sumatera Barat selama ini menggunakan metode ceramah. Proses perkuliahan dengan urutan diajarkan teori dan definisi, diberikan contoh, dan diberikan latihan soal tidak akan membuat mahasiswa aktif dalam pembelajaran, justru lebih menerima ilmu secara pasif (Siagian, 2016: 58). Jika mahasiswa mendapat kendala dalam pemahaman materi, mahasiswa tersebut lebih suka menunggu penjelasan dosen. Kebiasaan belajar yang hanya menunggu dan mengharapkan sepenuhnya penjelasan materi dari dosen belum cukup efektif dalam meningkatkan pemahaman mahasiswa terhadap materi ajar (Edriati, Anggraini \& Siska, 2015: 288). Pemahaman materi ajar yang kurang mengakibatkan hasil belajar rendah.

Hasil wawancara terhadap mahasiswa adalah mahasiswa masih mengalami kesulitan dalam memahami materi himpunan. Kesulitan memahami materi disebabkan karena buku teks yang ada belum bisa membuat mahasiswa belajar mandiri dan mahasiswa hanya menggunakan bahan ajar sesuai dengan anjuran dosen, belum bisa mencari buku teks yang lain. Hasil wawancara dengan dosen diperoleh bahwa metode pembelajaran yang digunakan oleh dosen adalah metode ceramah, diskusi dan tanya jawab. Buku teks yang digunakan dosen belum mampu mengkontruksi pengetahuan mahasiswa, sehingga pengetahuan tidak dibangun sendiri oleh mahasiswa dan pembelajaran menjadi kurang bermakna. Buku tersebut juga kurang memuat banyak latihan, sehingga mahasiwa kurang terlatih dalam pembahasan soal. Berdasarkan angket yang diberikan, diperoleh hasil bahwa mahasiswa selama ini membutuhkan waktu yang lama dalam memahami memahami materi. 
Pembelajaran yang efektif dapat meningkatkan hasil belajar. Pembelajaran tersebut akan terlaksana jika dosen dapat memilih strategi dan model pembelajaran yang tepat sehingga tercapai hasil yang semaksimal mungkin. Tahapan penting dalam kegiatan pembelajaran adalah memilih atau menentukan bahan ajar yang tepat dalam rangka membantu mahasiswa meningkatkan hasil belajar (Paradesa, Zulkardi \& Darmawijoyo, 2010: 96). Hal ini juga diperkuat oleh Ramdani (2012: 45) yang mengatakan bahwa bahan ajar merupakan bagian yang sangat penting dari suatu proses pembelajaran secara keseluruhan. Upaya yang dilakukan adalah pengembangan bahan perkuliahan berupa buku kerja. Buku kerja berupa buku berisikan sasaran belajar, teori singkat, latihan terstruktur dan tugastugas, soal-soal latihan serta bahan diskusi. Buku kerja memuat banyak latihan sehingga mahasiswa akan terlatih dalam menyelesaikan soal.

Peran dosen dalam kegiatan belajar mengajar adalah sebagai fasilitator dan motivator untuk mengoptimalkan belajar mahasiswa. Dosen seharusnya tidak hanya memberikan pengetahuan saja, tetapi mahasiswa aktif membangun pengetahuan dalam pikiran mereka sendiri (Misdalina, Zulkardi \& Purwoko, 2009: 62). Setyaningsih (2009: 13) mengatakan bahwa pembelajaran berbasis konstruktivis menuntut adanya suatu kegiatan yang memungkinkan mahasiswa membangun sendiri pengetahuan. Pernyataan Frederick (1981) yang dikutip Setyaningsih (2009: 13) menyebutkan prinsip konstruktivis (1) pengetahuan dibangun oleh maha- siswa (siswa) sendiri; (2) pengetahuan tidak dapat dipindahkan dari dosen (guru) ke mahasiswa (siswa); (3) mahasiswa (siswa) aktif mengkonstruksi sehingga terbentuk konsep ilmiah dan (4) dosen (guru) hanya membantu menyediakan sarana dan situasi agar proses konstruksi siswa berjalan mulus.

Hal ini juga diperkuat oleh Suparno (1997: 73) yang mengatakan bahwa prinsip-prinsip dari konstruktivisme antara lain pengetahuan dibangun oleh siswa secara aktif, tekanan dalam proses belajar terletak pada siswa, mengajar adalah membantu siswa belajar, tekanan dalam proses belajar lebih pada proses bukan pada hasil belajar, kurikulum menekankan partisipasi siswa, dan guru adalah fasilitator. Disampaikan juga oleh Elvinawati (2011:23), bahwa konstruktivisme merupakan aliran filsafat pengetahuan yang menekankan bahwa pengetahuan kita merupakan hasil konstruksi kita sendiri. Ciri mengenai konstruktivisme diberikan oleh Driver dan Oldham dalam Suparno (1997: 69), yaitu sebagai berikut. (1) Orientasi, mahasiswa diberi kesempatan untuk mengadakan observasi terhadap topik yang hendak dipelajari. (2) Elicitasi, mahasiswa dibantu mengungkapkan idenya secara jelas dengan berdiskusi, menulis, membuat poster, dan lain-lain. (3) Restrukturisasi ide, yaitu klarifikasi ide dengan ide-ide orang lain atau teman lewat diskusi ataupun lewat pengumpulan ide, membangun ide yang baru, dan mengevaluasi ide baru dengan eksperimen. (4) Penggunaan ide dalam banyak situasi. (5) Review, bagaimana ide itu berubah. 
Pembelajaran konstruktivisme, akan membuat siswa menjadi aktif karena pembelajaran tidak ditekankan pada hasil namun pada proses dan guru hanya menjadi fasilitator. Sardiman (2010:101) berpendapat bahwa aktivitas belajar adalah aktivitas yang bersifat fisik ataupun mental. Mahasiswa yang melakukan aktivitas fisik berarti mereka aktif dengan anggota badan, tidak hanya duduk, melihat, dan mendengarkan. Sedangkan mahasiswa yang melakukan aktivitas bersifat mental adalah jika mahasiswa tersebut dapat mengumpulkan dan mengolah data, menyusun hipotesis, dan melaksanakan eksperimen. Selain mahasiswa aktif, hasil belajar juga akan meningkat. Hasil belajar diperoleh setelah adanya kegiatan belajar, yang merupakan suatu proses seseorang untuk memperoleh sesuatu yang baru dan perubahan tingkah laku sebagai hasil dari pengalaman belajar. Melalui hasil belajar dapat dilihat sejauh mana pemahaman mahasiswa terhadap materi yang diajarkan. Menurut Bloom yang dikutip dari Sudijono (2005: 49), hasil belajar dibagi dalam 3 ranah kawasan, yaitu kognitif, psikomotor, dan afektif. Kategori dan proses kognitif kemampuan manusia menurut Ibrahim dalam Amdal (2008), merupakan revisi dari taksonomi yang disusun oleh Bloom, dkk yaitu: (1) mengingat, (2) memahami, (3) menerapkan, (4) menganalisis, (5) mengevaluasi, (6) menciptakan.

Oleh karena itu, buku kerja yang dikembangkan adalah buku kerja berbasis konstruktivime. Dengan mempelajari buku kerja berbasis konstruktivisme, mahasiswa akan aktif mengkonstruksi pengetahuan. Mahasiswa diberi kesempatan mengemukakan gagasan dan berdiskusi dengan temannya. Seiring dengan pemakaian buku kerja berbasis konstruktivisme, diharapkan aktivitas dan hasil belajar mahasiswa meningkat. Buku kerja (bahan ajar) harus memadai untuk penelitian artinya harus tervalidasi (Ramdani, 2012:45), maka buku kerja ini akan divalidasi oleh pakar bidangnya. Penelitian ini bertujuan untuk mengetahui validitas buku kerja berbasis konstruktivisme untuk materi himpunan. Penelitian ini diharapkan bermanfaat bagi dosen sebagai bahan ajar perkuliahan sehingga aktivitas dan hasil belajar mahasiswa akan meningkat.

\section{METODE PENELITIAN}

Penelitian ini merupakan penelitian pengembangan. Menurut Isandespha (2015: 5), penelitian pengembangan adalah sebuah proses yang digunakan untuk mengembangkan dan memvalidasi produk. Penelitian pengembangan ini menggunakan model umum desain penelitian Plomp (2013: 19) yang terdiri atas 3 fase yaitu preliminary research, prototyping phase, dan assessment phase. Fase preliminary research telah dilakukan analisis masalah dan studi literatur dan telah selesai dilaksanakan. Prototyping phase adalah tahap pembuatan prototipe. Assessment phase adalah tahap menilai apakah pengguna dapat menggunakan buku kerja (praktikalitas) dan berkeinginan untuk mengaplikasikannya, serta untuk menilai efektivitas buku kerja. Tahap yang dilakukan pada penelitian ini sampai tahap prototyping phase, yaitu melakukan validasi buku kerja. 
Kegiatan yang dilakukan pada tahap prototyping phase adalah (1) merancang sistematika dan struktur buku kerja berbasis kontrukti-visme dan melakukan evaluasi diri. Selanjutnya, dilakukan analisis dan revisi desain sistematika dan struktur buku kerja berbasis konstruktivisme, (2) menyusun prototipe buku kerja berdasarkan desain sistematika dan struktur buku kerja, melakukan evaluasi diri, menganalisis dan merevisi prototipe berdasarkan hasil evaluasi diri, dan (3) melakukan validasi isi dan konstruk (tinjauan ahli) terhadap prototipe buku kerja, menganalisis, dan merevisi prototipe berdasarkan hasil tinjauan ahli.

Instrumen yang digunakan adalah lembar validasi. Lembar validasi digunakan untuk mengetahui validitas buku kerja yang dikembangkan. Validitas mengacu pada sejauh mana materi dalam buku kerja yang dikembangkan didasarkan pada sumber ilmu (validitas isi) dan bahwa berbagai komponen buku kerja secara konsisten dihubungkan satu sama lain (validitas konstruk). Aspek yang diamati dalam penilaian validitas terdiri atas empat aspek yaitu penyajian, kelayakan isi, kebahasaan, dan kegrafikaan. Kegiatan validasi dilakukan sampai diperoleh buku kerja yang valid. Validasi dilakukan oleh pakar pendidikan matematika. Skala penilaian untuk lembar validasi menggunakan skala Likert dengan empat alternatif pilihan jawaban yaitu sangat, setuju (SS), setuju (S), tidak setuju (TS), sangat tidak setuju (STS).

Instrumen selanjutnya adalah pedoman evaluasi diri. Pedoman evaluasi diri digunakan untuk mengetahui kesalahan-kesalahan dalam menyusun rancangan draft buku kerja berbasis konstruktivisme. Hasil evaluasi diri digunakan untuk merevisi draft buku kerja sebelum dilakukan tinjauan ahli. Aspek yang diamati dalam evaluasi diri adalah penyajian, kelayakan isi, kebahasaan, dan kegrafikaan.

Hasil validasi terhadap seluruh aspek yang diamati, disajikan dalam bentuk tabel, selanjutnya dicari rerata skor tersebut. Rerata yang didapatkan dikonfirmasi dengan kriteria yang ditetapkan. Cara mendapatkan kriteria tersebut adalah dengan menetapkan rentang skor dimulai dari 1 ( $\mathrm{sr}=$ skor rendah) sampai 4 (st $=$ skor tinggi). Rentang skor tersebut dibagi menjadi empat kelas interval. Kriteria setiap interval dikategorikan atas lima tingkatan seperti pada Tabel 1 .

Tabel 1. Kriteria Validitas Instrumen dan Buku kerja

\begin{tabular}{cc}
\hline Rerata $(\mathrm{R})$ & Kriteria \\
\hline $3,00<\mathrm{R} \leq 4,00$ & Sangat Valid \\
$2,50<\mathrm{R} \leq 3,25$ & Valid \\
$1,75<\mathrm{R} \leq 2,50$ & Kurang Valid \\
$1,00 \leq \mathrm{R} \leq 1,75$ & Tidak Valid \\
\hline
\end{tabular}

\section{HASIL DAN PEMBAHASAN}

Pada tahap prototyping phase, dilakukan terlebih dahulu merancang sistematika dan struktur buku kerja. Revisi sistematika dan struktur buku kerja dilakukan. Buku kerja sebelumnya belum memuat judul materi pokok dan kunci jawaban. Alasan judul materi pokok dicantumkan sebelum uraian materi adalah agar mahasiswa nengetahui materi apa saja yang akan dipelajari. Kunci jawaban juga dicantumkan agar mahasiswa lebih 
termotivasi dalam pengerjaan latihan. Sistematika dan struktur buku kerja setelah direvisi sebagai berikut.

Tabel 2. Hasil Revisi Rancangan Struktur

\begin{tabular}{ll}
\multicolumn{2}{c}{ Buku Kerja } \\
\hline BAB 1 & BAB 2 \\
1. materi pokok & 1. materi pokok \\
2. uraian materi & 2. uraian materi \\
himpunan dan & operasi \\
subhimpunan & himpunan dan \\
3. contoh soal & aljabar himpunan \\
4. latihan & 3. contoh soal \\
5. referensi & 4. latihan \\
6. kunci jawaban & 5. referensi \\
& 6. kunci jawaban
\end{tabular}

\section{BAB $3 \quad$ BAB 4}

1. mareri pokok 1. materi pokok

$\begin{array}{lll}\text { 2. uraian materi relasi } & \text { 2. uraian materi }\end{array}$

3. contoh soal fungsi

4. latihan 3. contoh soal

5. referensi 4. latihan

6. kunci jawaban 5. referensi

6. kunci jawaban

BAB 5

BAB 6

1. materi pokok 1. materi pokok

2. uraian materi pernya- 2. uraian materi taan dan operasinya argumen dan

3. contoh soal

4. latihan metode deduksi

5. referensi

3. contoh soal

6. kunci jawaban

4. latihan

5. referensi

6. kunci jawaban

BAB 7

1. materi pokok

2. uraian materi kuantor dan teori kuantifikasi

3. contoh soal

4. latihan

5. referensi

6. kunci jawaban

Setelah rancangan buku kerja telah selesai dibuat, maka disusun prototipe buku kerja sesuai dengan rancangan tersebut. Pada bagian awal, terdapat judul materi pokok. Mahasiswa akan mengetahui materi apa saja yang akan dipelajari. Gambar 1 adalah contoh materi pokok yang diberikan.

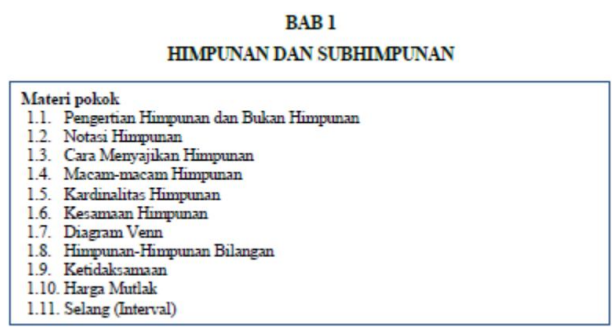

Gambar 1. Contoh Materi Pokok

Setelah materi pokok, selanjutnya bagian uraian materi. Pada uraian materi memuat ciri konstruktivis. Orientasi merupakan salah satu ciri konstruktivis. Pada bagian ini ditampilkan gambar suatu kumpulan buah dan dikatakan kumpulan tersebut adalah himpunan. Mahasiswa diberi kesempatan untuk mengadakan observasi serta mencermati alasan kumpulan buah tersebut dikatakan himpunan.

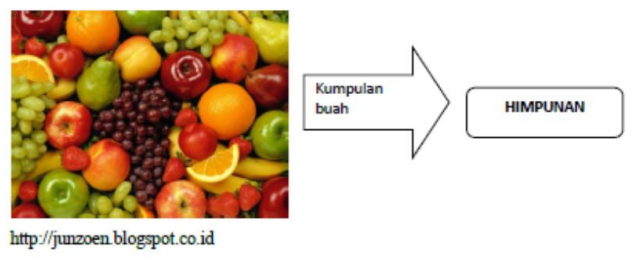

Gambar 2. Uraian Materi (Orientasi)

Ciri konstruktivis selanjutnya adalah elicitasi. Elicitasi pada buku kerja ini mahasiswa diharuskan menuliskan ide atau gagasan mereka pada kotak kosong. Berdasarkan gambar sebelumnya, mahasiswa diminta menuliskan ciri atau karakteristik dari kumpulan buah tersebut pada kotak kosong. Pada bagian restrukturisasi ide, mahasiswa juga dapat berdiskusi untuk mengklarifikasi menge- 
nai ide atau gagasan mereka sebelumnya. Hasil dari klarifikasi ide tersebut juga dapat dituliskan pada kotak kosong. Contoh dapat dilihat pada Gambar 3.

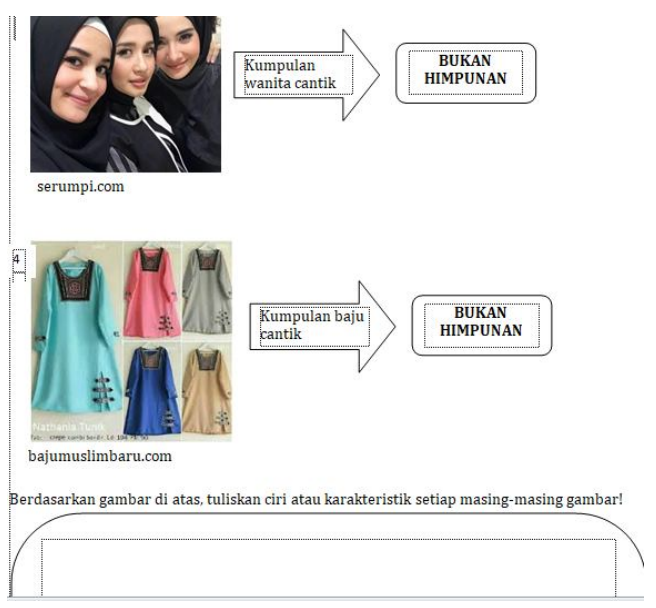

Gambar 3. Uraian Materi

(Elicitasi dan Restrukturisasi Ide)

Ide atau gagasan mengenai ciri dari kumpulan buah tersebut dihubungkan dengan alasan kumpulan buah dikatakan himpunan. Hal ini merupakan bagian ciri konstruktivis, yaitu penggunaan ide dalam banyak situasi yang dapat dilihat pada Gambar 4.

Selanjutnya hubungkan mengapa kumpulan burung hantu dan kumpulan buah disebut himpunan, sedangkan kumpulan lukisan indah bukan himpunan dengan ciri atau karaltersitik dari setiap kumpulan tersebut. cin ataukarahtersitak dani setiapkumpulan tersebut.

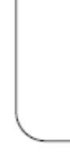

Gambar 4. Uraian Materi

(Penggunaan Ide dalam Banyak Situasi)

Berdasarkan ide sebelumnya, maka ide atau gagasan mahasiswa mengenai gambar yang termasuk himpunan dan bukan himpunan, maka mahasiswa dapat menyimpulkan dengan apa yang dimaksud dengan himpunan dan bukan himpunan. Kesimpulan mereka merupakan bagian dari review yang dapat dilihat pada Gambar 5 .

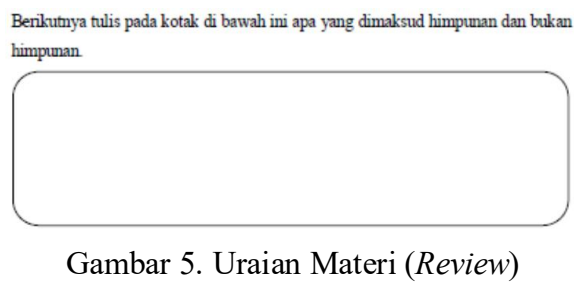

Setelah memahami uraian materi yang memuat ciri konstruktivis, maka mahasiwa memahami contoh soal beserta jawabannya. Contoh berguna dipelajari mahasiswa agar pemahaman mengenai materi bertambah. Contoh berhubungan materi yang dijelaskan sebelumnya. Gambar 6 adalah salah satu bentuk contoh pada buku kerja.

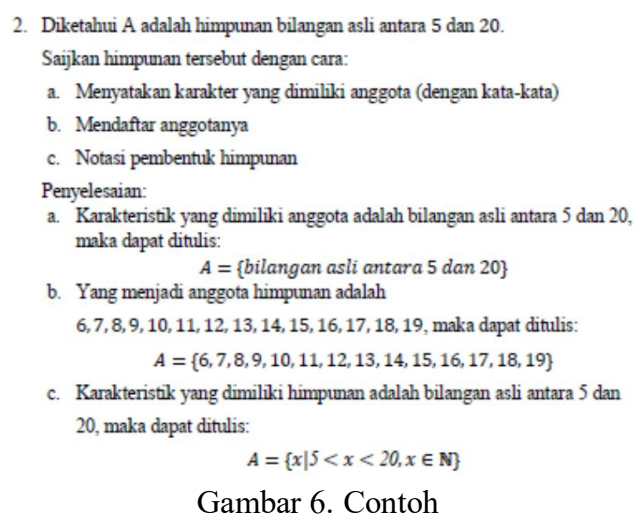

Struktur buku kerja selanjutnya adalah latihan. Kemampuan mahasiswa dapat diukur melalui latihan. Soal-soal latihan diambil dari soal-soal yang terdapat dalam buku Logika Matematika Elementer karangan Kusumah, Teori Himpunan karangan Pantur Silaban, dan Pengantar Dasar Matematika karangan Bachtiar Syarif, serta referensi tambahan lain. Gambar 7 menyajikan salah satu contoh latihan. 


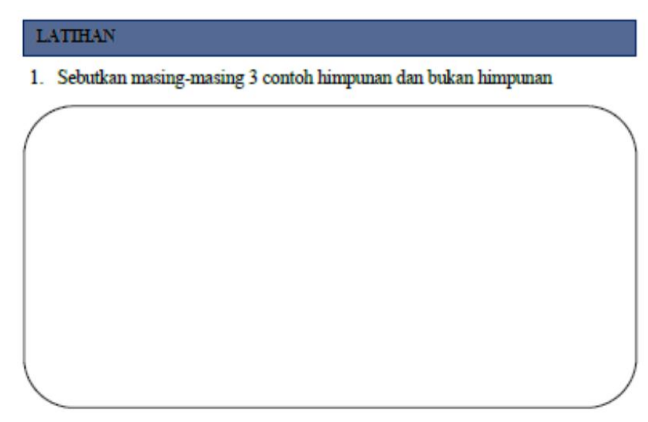

Gambar 7. Latihan

Kunci jawaban latihan berada pada bagian akhir buku kerja. Kunci jawaban berguna agar mahasiswa dapat mencocokkan jawaban mereka dengan jawaban yang benar serta memotivasi mereka untuk dapat menyelesaikan semua latihan. Contoh kunci jawaban diberikan pada Gambar 8.

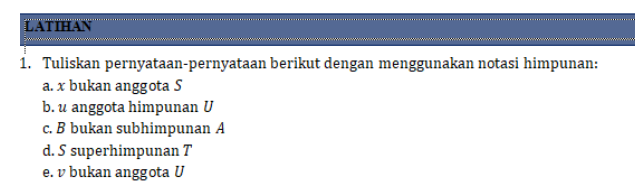

KUNCI JAWABAN

$$
\begin{aligned}
& \text { Latihan BAB } 1 \\
& \text { 1. a. } x \notin S \\
& \text { b. } u \in U \\
& \text { c. } B \notin \subset A \\
& \text { d. } S \supset T \\
& \text { e. } v \notin U
\end{aligned}
$$

Gambar 8. Kunci Jawaban Latihan

Setelah dilakukan pembuatan prototipe buku kerja, maka dilakukan evaluasi diri terhadap buku kerja tersebut. Setelah dilakukan revisi berdasarkan hasil evaluasi diri, maka buku kerja tersebut divalidasi berdasarkan tinjauan ahli. Validator memberikan saran dan perbaikan. Tabel 3 menyajikan perbaikan yang disarankan oleh validator.
Tabel 3. Saran Validator beserta Perbaikan

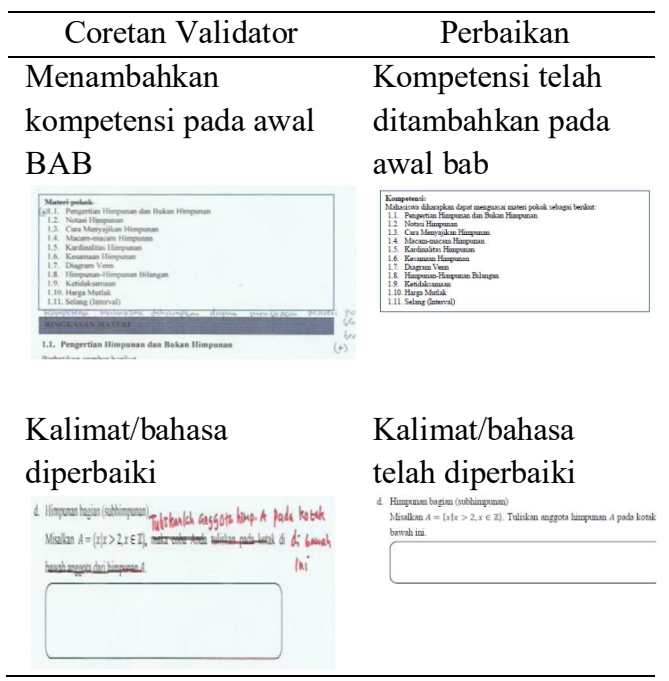

Revisi buku kerja dilakukan berdasarkan saran validator. Buku kerja yang telah direvisi divalidasi kembali. Hasil validasi dapat dilihat pada Tabel 4.

Tabel 4. Hasil Validasi

\begin{tabular}{lcccc}
\hline \multirow{2}{*}{$\begin{array}{c}\text { Aspek yang } \\
\text { Dinilai }\end{array}$} & $\begin{array}{c}\text { Skor } \\
\text { Validator } \\
\text { ke- }\end{array}$ & $\begin{array}{c}\text { Rata- } \\
\text { Rata } \\
\text { Skor }\end{array}$ & Kriteria \\
\cline { 2 - 3 } & 1 & 2 & & \\
\hline Kelayakan Isi & 2,67 & 3,00 & 2,87 & Valid \\
Penyajian & 3,00 & 2,33 & 2,67 & Valid \\
Kebahasaan & 3,00 & 2.71 & 2,86 & Valid \\
Kegrafikan & 3,00 & 2,75 & 2,88 & Valid \\
Rata-rata & & & 2,82 & Valid \\
\hline
\end{tabular}

\section{PEMBAHASAN}

Buku kerja berbasis konstruktivisme untuk materi himpunan perlu divalidasi untuk memperoleh buku kerja yang tepat sehingga dapat digunakan sebagai bahan perkuliahan. Ramdani (2012:46) mengatakan validasi dilakukan oleh pakar agar memenuhi teori yang ajeg dan sesuai dengan kaidah ilmiah. Validitas yang dilakukan pada penelitian ini menekankan pada validitas isi dan konstruk. Berdasarkan hasil validasi buku kerja berbasis konstruktivisme 
dapat diketahui bahwa buku kerja yang dikembangkan memperoleh rata-rata skor validasi adalah 2,82. Dengan merujuk kepada kriteria, buku kerja berbasis konstruktivisme dapat dikatakan valid dari segi isi dan konstruk. Buku kerja berbasis konstruktivisme yang valid dari segi isi berarti buku kerja berbasis konstruktivisme yang telah dirancang sesuai dengan kompetensi mata kuliah Pengantar Dasar Matematika untuk materi himpunan, sedangkan valid dari segi konstruk berarti komponen-komponen buku kerja berbasis konstruktivisme tersebut sesuai dengan indikator-indikator yang telah ditetapkan.

Validitas buku kerja berbasis konstruktivisme dapat diuraikan sebagai berikut.

a. Berdasarkan kelayakan isi, materi pada buku kerja telah disajikan sesuai dengan kompetensi yang ingin dicapai. Konsep-konsep materi himpunan dipertegas dengan gambar. Majid (2006:176) memaparkan bahwa buku yang baik adalah buku yang disajikan secara menarik dilengkapi dengan gambar dan keterangan-keterangannya. Materi yang disajikan dapat mengkontruksi pengetahuan mahasiswa sudah sesuai dengan ciri konstruktivis. Ini juga sudah sesuai dengan yang disebutkan Rosnamawati (2009: 509) mengatakan bahwa pembelajaran matematika menurut pandangan konstruktivis adalah memberikan kesempatan kepada mahasiswa untuk mengkonstruksi konsep matematika dengan kemampuan sendiri melalui proses internalisasi. Contoh soal dan latihan relevan dengan materi yang disajikan, yang disadur dari buku teks Logika Matematika Elementer Karangan Yahya Kusuma.

b. Kompetensi pendukung dan cara mempelajari materi telah disajikan dengan jelas. Penyajian materi telah memunculkan proses membangun pemahaman konsep, karena buku kerja ini sudah memuat ciri konstruktivis berupa orientasi, elicitasi, restrukturisasi ide, penggunaan ide dalam banyak situasi, dan aplikasi. Hal ini senada diungkapkan oleh Setyaningsih (2009: 13), yaitu pembelajaran berbasis konstruktivis menuntut adanya suatu kegiatan yang memungkinkan mahasiswa membangun sendiri pengetahuan. Buku kerja telah menyajikan pertanyaan yang akan menjadi fokus dalam membangun pemahaman konsep. Ide atau gagasan dari pertanyaan tersebut dapat dituliskan pada kotak kosong. Dengan adanya kotak tersebut, mahasiswa diharuskan menuliskan ide sehingga mahasiswa menjadi lebih aktif dalam proses pembelajaran. Nurhajati (2014:1) mengatakan bahwa pendekatan konstruktivisme mampu meningkatkan keaktifan siswa, siswa mampu menyampaikan ide-ide atau gagasan yang berhubungan dengan materi yang sedang dipelajari, sehingga mampu meningkatkan kemampuan matematis siswa. Dengan cara seperti ini, dosen telah menempatkan diri sebagai fasilitator dan motivator. Dengan meningkatnya partisipasi mahasiswa akan berdampak pada meningkatnya kemampuan berpikir kritis dan kreatif (Setya- 
ningsih, 2009: 21). Meningkatnya kemampuan berpikir kritis tentunya akan meningkatkan hasil belajar mahasiswa. Hal ini diperkuat oleh Mulbar yang dikutip Fadillah dan Jamilah (2016:112) menyimpulkan bahwa penggunaan model pembelajaran dengan mengoptimalkan aktivitas dan kreativitas mahasiswa, akan berimplikasi positif terhadap kesuksesan belajar seseorang.

c. Penggunaan bahasa dalam mengembangkan bahan ajar menjadi salah satu faktor yang penting. Pemilihan ragam bahasa dan pemilihan kata dalam menyusun kalimat efektif akan berpengaruh terhadap kualitas bahan ajar. Penggunaan bahasa komunikatif akan membuat mahasiswa merasa seolah-olah berinteraksi dengan dosennya melalui tulisan-tulisan dalam bahan ajar tersebut (Fadillah \& Jamilah, 2016:110). Oleh karena itu, kalimat yang digunakan adalah kalimat yang disesuaikan dengan tingkat pemahaman mahasiswa. Latihan yang dikembangkan juga menggunakan tata bahasa yang sesuai dengan kaidah bahasa Indonesia

d. Desain cover dan bagian isi sudah menarik. Bahan ajar yang menarik dapat membangkitkan semangat mahasiswa untuk belajar. Penggunaan warna, jenis, dan ukuran tulisan dalam buku kerja sudah konsisten.

\section{PENUTUP}

Berdasarkan hasil dan pembahasan, diperoleh kesimpulan bahwa buku kerja telah valid dari segi kelayakan isi, penyajian, kebahasaan, dan kegrafikan. Buku kerja memuat ciri konstruktivis, yaitu orientasi, elicitasi, restrukturisasi ide, penggunaan ide dalam banyak situasi, dan aplikasi.

\section{DAFTAR PUSTAKA}

Elvinawati. (2011). Optimalisasi Pembelajaran Kimia Pemisahan Melalui Penerapan Pendekatan Konstruktivisme dan Model Peta Konsep. Jurnal Exacta, Vol. IX, No. 1 Juni 2011 ISSN 1412-3617, 23-28.

Fadillah, S., \& Jamilah. (2016). Pengembangan Bahan Ajar Struktur Aljabar untuk Meningkatkan Kemampuan Pembuktian Matematis Mahasiswa. Cakrawala Pendidikan, Februari 2016, Th. XXXV, No. 1, 106-113.

Isandespha, I.N. (2015). Pengembangan Bahan Ajar Materi Pembelajaran Matematika SD dengan Pendekatan Realistik Bernuansa Islami untuk Mahasiswa Pendidikan Guru Sekolah Dasar. Elementary School, Vol. 2 No. 1 Januari 2015 ISSN 2338-980X, 112.

Edriati, S., Anggraini, A., \& Siska, M. (2015). Efektivitas Model Jigsaw disertai Penilaian Diskusi untuk Meningkatkan Kemampuan Matematis Mahasiswa. Cakrawala Pendidikan, Juni 2015, Th. XXXIV, No.2, 288-295.

Majid, Abdul. 2006. Perencanaan Pembelajaran: Mengembangkan Standar Kompetensi Guru. Bandung: Remaja Rosdakarya.

Misdalina, Zulkardi \& Purwoko. (2009). Pengembangan Materi Integral untuk Sekolah Menengah Atas (SMA) Menggunakan Pendekatan Pendidikan Matematika Realistik 
Indonesia (PMRI) di Palembang. Jurnal Pendidikan Matematika Volume 3, No. 1, Januari 2009, 6174.

Nugraha, A., \& Dwiyana, A. S. (2014). Dasar-dasar Matematika dan Sains. PAUD4305/Modul1.

Nurhajati. 2014. Pengaruh Penerapan Pendekatan Konstruktivisme dengan Model Pembelajaran Kooperatif Program Cabri 3D terhadap Kemampuan Penalaran dan Konsek Matematis Siswa SMA di Kota Tasikmalaya. Jurnal Pendidikan dan Keguruan. Vol. 1, No. pasca.ut.ac.id/journal/index.php/J PK/article/download/6/6. 2014.

Paradesa, R., Zulkardi \& Darmawijoyo. (2010). Bahan Ajar Kalkulus 2 Menggunakan Macromedia Flash dan Maple di STKIP PGRI Lubuklinggau. Jurnal Pendidikan Matematika, Volume 4, No. 1, Juni 2010, 95-109.

Plomp, T. 2013. "Educational Design Research an Introduction", dalam Tjeerd Plomp dan Nienke Nieveen (Eds.), Educational Design Reserach Part A: An Introduction (hlm. 9-35). Enschede: slo.

Ramdani Y. (2012). Pengembangan Instrumen dan Bahan Ajar untuk Meningkatkan Kemampuan Komunikasi, Penalaran, dan Koneksi Matematis dalam Konsep Integral. Jurnal Penelitian Pendidikan. Vol. 13. No. 1, April 2012, 44-52.
Rosnawati R. (2009, 16 Mei). Enam Tahapan Aktivitas dalam Pembelajaran Matematika untuk Mendayagunakan Berpikir Tingkat Tinggi Siswa. Artikel dipresentasikan pada Seminar Nasional Penelitian, Pendidikan dan Penerapan MIPA Fakultas MIPA, Universitas Negeri Yogyakarta.

Setyaningsih N. (2009). Peningkatan Kemampuan Berpikir Kritis dan Kreatif Mahasiswa dalam Pemecahan Masalah Pengantar Dasar Matematika melalui Pendekatan Pembelajaran Berbasis Konstruktivis. Varia Pendidikan, Vol. 21, No. 1, Juni 2009, 12-23.

Sardiman. 2010. Interaksi dan Motivasi Belajar Mengajar. Jakarta: PT Raja Grafindo Persada.

Siagian, MD. (2016). Kemampuan Konseksi Matematika dalam Pembelajaran Matematika. MES (Journal of Mathematics Education and Science) ISSN: 2528-4363. Vol. 2, No.1, Oktober 2016, 58-67.

Sudijono, Anas. 2005. Pengantar Statistik Pendidikan. Jakarta: Raja Grafindo Persada.

Suparno, Paul. 1997. Filsafat Konstruktivisme dalam Pendidikan. Yogyakarta: Kanisius. 